Document downloaded from:

http://hdl.handle.net/10251/60268

This paper must be cited as:

Calatayud, V.; García Breijo, FJ.; Cervero, J.; Reig Armiñana, J.; Mã JOSE SANZ SÁNCHEZ (2011). Physiological,anatomical and biomass partitioning responses to ozone in the Mediterranean endemic plant Lamottea dianae. Ecotoxicology and Environmental Safety. 74(5):1131-1138. doi:10.1016/j.ecoenv.2011.02.023.



The final publication is available at

http://dx.doi.org/10.1016/j.ecoenv.2011.02.023

Copyright Elsevier

Additional Information 


\title{
Physiological, anatomical and biomass partitioning responses to ozone in the Mediterranean endemic plant Lamottea dianae
}

\author{
Vicent Calatayud ${ }^{\mathrm{a}, *}$, Francisco J. García-Breijo ${ }^{\mathrm{b}, \mathrm{c}}$, Júlia Cervero a ${ }^{\mathrm{a}}$ José Reig-Armiñana ${ }^{\mathrm{b}}$, María José Sanz ${ }^{\mathrm{a}}$ \\ a Instituto Universitario CEAM-UMH, Charles R. Darwin 14, Parc Tecnològic, 46980 Paterna, Valencia, Spain \\ b Laboratorio de Anatomía e Histología Vegetal "Julio Iranzo", Jardín Botánico, Universitat de València, c/Quart, 80, 46008 Valencia, Spain \\ ' Departamento de Ecosistemas Agroforestales, Escuela Técnica Superior de Ingeniería Agronómica y del Medio Natural (ETSIAMN), Universidad Politécnica de Valencia (UPV), \\ Camino de Vera s/n, 46022 Valencia, Spain
}

\section{A R T I C L E I N F O}

\section{Keywords:}

Ozone

Oxidative stress

Photosynthesis

Rubisco

Biomass partitioning

Anatomy

Endemic plants

\begin{abstract}
A B S T R A C T
Ozone effects on the perennial forb Lamottea dianae were studied in an open-top chamber experiment. Ozone was found to induce reductions in $\mathrm{CO}_{2}$ assimilation and water use efficiency in the leaves of this species. These reductions were mainly related to a decline in the in vivo $\mathrm{CO}_{2}$ fixation capacity of Rubisco $\left(V_{c, \max }\right)$, rather than to stomatal limitations or photoinhibitory damage $\left(F_{v}: F_{m}\right)$. In addition to chloroplast degeneration, other observed effects were callose accumulation, formation of pectinaceous wart-like cell wall exudates and phloem alterations. Moreover, ozone exposure significantly reduced root dry biomass. The possible relevance of these adverse effects for Mediterranean forbs is commented. These results show that endemic plants can be very sensitive to ozone, suggesting that risks associated with this pollutant should be taken into account for conservation purposes.
\end{abstract}

\section{Introduction}

Tropospheric ozone is the most important air pollutant toxic to plants worldwide, causing crop losses and inducing a series of adverse effects on native vegetation (Krupa et al., 2000). In Europe, some of the highest ozone levels occur in the Mediterranean Region (Sanz et al., 2007). This area can be regarded as a

Abbreviations: $A_{\max }$, net $\mathrm{CO}_{2}$ assimilation per unit area under light and $\mathrm{CO}_{2}$ saturation; $A_{\text {sat }}$, net $\mathrm{CO}_{2}$ assimilation per unit area under light saturation; AOT40 accumulated ozone exposure over a threshold of $40 \mathrm{ppb}\left(=80 \mathrm{\mu g} \mathrm{m}^{-3}\right)$ calculated for daylight hours; $C_{i}$, intercellular $\mathrm{CO}_{2}$ concentrations; $\mathrm{CF}$, charcoal-filtered treatment; $\Phi_{\text {exc }}$, quantum efficiency of excitation capture by oxidized reaction centers of PSII; $\Phi_{P S I I}$, quantum yield of electron transfer at PSII; $F_{m}$, maximum fluorescence; $F_{m}{ }^{\prime}$, maximum fluorescence in the light adapted state; $F_{o}$, minimal fluorescence; $F_{o}{ }^{\prime}$, minimum fluorescence in the light-adapted state; $F_{s}$, fluorescence yield at this steady state; $F_{v}: F_{m}$, maximum quantum efficiency of photosystem II (PSII) primary photochemistry; $g_{s}$, stomatal conductance to water vapor; $J_{\max }$, maximum RuBP regeneration capacity mediated by light harvesting and electron transport; NF +30 , Non-filtered +30 ppb of ozone treatment; NPQ, quenching due to non-photochemical dissipation of absorbed light energy; PII, Plant Injury Index; PPFD, photosynthetic photon flux density; RSL, relative stomatal limitation; $\mathrm{qP}$, coefficient for photochemical quenching; $R_{d}$, daytime respiration; TPU, rate of triose phosphate utilization; $T_{r}$, transpiration rate; $V_{c, \max }$ maximum rate of Rubisco carboxylation

* Corresponding author. Fax:+34961318190.

E-mail addresses: calatayud_viclor@gva.es, vicent@ceam.es (V. Calatayud). "large natural photochemical reactor" (Millán et al., 1996), with the polluted air masses undergoing complex long-range transport processes (Lelieveld et al., 2002). Under some of the conditions described by the IPCC, ozone levels are expected to increase worldwide (Vingarzan, 2004) which, in addition to the continuous increase in population, industry and traffic in the Mediterranean area, will probably favor a higher frequency of ozone episodes in this region.

Up to now, very little work has been done on the effects of pollutants in endemic or rare plant species. Species with relatively small populations may be more vulnerable to pollution and other threats not only because of their reduced distribution areas or low number of individuals, but also due to their lower genetic variability, which may limit their possibilities of adaptation to changes in their habitat. From a botanical point of view, the Mediterranean Region is a major center of diversity in Europe, hosting many plants that are either endemic or/and of restricted distribution. As an example, of the 9000 species in the Spanish flora, 1414 taxa are included in the Red List (Domínguez-Lozano, 2000) and more than 400 are endangered. Lamottea dianae (Webb) G. López (=Carduncellus dianius Webb) (Fam. Asteraceae) is an endemism from Spain, classified as "Vulnerable" on the Red List of Spanish Vascular Flora (DomínguezLozano, 2000). Efforts to protect this species have led to preserving its habitat through micro-reserves, in vitro micro-propagation and re-introduction (Laguna et al., 1998). 
The main objective of the present paper is to determine the vulnerability of $L$. dianae to increasing ozone levels by studying its physiological, anatomical and biomass responses against this pollutant. A complementary study showed that ozone produced both a significant reduction in the number of flowers produced per plant and an increase in altered pollen cell production in this species (García-Breijo et al., 2005).

\section{Materials and methods}

\subsection{Plant material}

Plant seedlings were obtained from the Vivero de Quart nursery, Banc de Llavors Forestals (Valencia). The origin of the seeds was El Montgó (Alicante, Comunidad Valenciana). The 71 containers were filled with $50 \%$ coconut-peat, $30 \%$ peat, $10 \%$ sand and $10 \%$ vermiculite, soil $\mathrm{pH}$ being close to 7.0 . A slow-release fertilizer was incorporated (Osmocote plus), with NPK 20:10:20. Plants were irrigated twice a day until field capacity using a droplet irrigation system. Twelve plants were kept in filtered air, and another 12 were ozone-exposed.

\subsection{Open-top chambers and ozone exposure}

The experiment was conducted in the OTC experimental field that the Instituto Universitario CEAM-UMH operates in Benifaió (Comunidad Valenciana, $39^{\circ} 16^{\prime} 14.8^{\prime \prime} \mathrm{N}, 00^{\circ} 26^{\prime} 59.6^{\prime \prime} \mathrm{W}, 30 \mathrm{~m}$ altitude). Plants were distributed in six Opentop chambers (OTC), 3-m diameter (NCLAN model, Heagle et al., 1973), with two ozone treatments (three chambers per treatment): Charcoal filtered air (CF) and non-filtered air plus $30 \mathrm{ppb}$ ozone $(\mathrm{NF}+30)$. As ozone levels are relatively low at the experimental plot, the latter regime is more representative of the higher ozone concentrations measured in mountain areas of eastern Spain (Millán et al., 2000). Ozone was generated from oxygen using a high-voltage electrical discharge generator (Sir sa), and air quality inside and outside the chambers was continuously monitored at regular intervals with an ozone monitor (Dasibi 1008-AH, Environmental Corp.). The experiment started on 18 May 2005, and ended on 8 September 2005, when the plants were harvested. All week long, the plants were ozone-exposed $8 \mathrm{~h}$ a day, from 10:00 to 18:00 CET. For the exposure period, the 24, 12 and $8 \mathrm{~h}$ means were calculated, as well as the AOT40, i.e. accumulated ozone exposure over a threshold of $40 \mathrm{ppb}\left(80 \mu \mathrm{g} \mathrm{m}^{-3}\right)$, based on hourly averages, during daylight hours from 8:00 to 20:00, as described by the EU 2002/3/EC Directive (EU, 2002). Plants were grown together with other species and regularly moved inside chambers and among chambers of the same treatment in order to avoid positional effects.

\subsection{Assessment of visible symptoms}

All plants were examined daily to detect the first symptom in each plant. The intensity of the visible ozone symptoms was also scored weekly by recording both the percentage of affected leaves per plant (LA), and the mean percentage of area affected for the symptomatic leaves (AA) in each plant, using a $5 \%$ step scale. To evaluate the overall plant injury, a Plant Injury Index (PII) was calculated by combining these two parameters: $\mathrm{PII}=(\mathrm{LA} * \mathrm{AA}) / 100$.

\subsection{Microscopy methods}

Samples of mature leaves were randomly selected from control and from fumigated plants (five plants per treatment, one leaf per plant) on 8 June 2005 . Some portions of these leaves were fixed in situ with formyl acetic alcohol (FAA). After washing them with a $0.1 \mathrm{M}$ phosphate buffer ( $\mathrm{pH} 7.4$ ), they were dehydrated by means of an ethanol series. Some samples were cut in sections of approximately $20 \mu \mathrm{m}$ with a freezing microtome (CM 1325, Leica, Wetzlar, Germany). Callose was detected by fluorescence microscopy after aniline blue staining. Other portions of the collected leaves were embedded in LR-White medium-grade acrylic resin (London Resin Co.). The sectioning of these latter blocks was performed with a Sorvall MT 5000 Ultramicrotome (Knifemaker, Reichert-Jung) provided with special glasscutters $\left(45^{\circ}\right)$ (Leica $6.4 \mathrm{~mm}$ glass strips). This microtome enabled semi-thin sections $(1.5 \mu \mathrm{m})$. These samples were stained with toluidine blue (1\%) (TB). Sections were observed and photographed with an Olympus Provis AX 70 brightfield microscope fitted with an Olympus Camedia C-2000 Z camera.

\subsection{Gas exchange, chlorophyll content and chlorophyll a fluorescence measurements}

Eight of the twelve plants per treatment were selected for the gas exchange, chlorophyll content and chlorophyll fluorescence measurements. Measurements were carried out in asymptomatic parts of leaves (one leaf per plant for each treatment), on 4 June 2005, 3 weeks after starting the ozone exposure, from 8:00 to 11:00 CET. Complementary measurements on symptomatic leaves were also carried out, but not shown

Gas exchange measurements were taken with an infrared gas analyzer (IRGA) (LICOR-6400, Li-cor Inc., Lincon, NE, USA). In order to reduce the possible effects of changes in environmental variables during the measurements, cuvette block temperature was fixed at $25^{\circ} \mathrm{C}$, photon flux density (PPFD) was at a saturating value of $1200 \mu \mathrm{mol} \mathrm{m}^{-2} \mathrm{~s}^{-1}$, and the reference $\mathrm{CO}_{2}$ concentration was $370 \mu \mathrm{mol} \mathrm{mol}{ }^{-1}$. Relative humidity during the measurements was $46.9 \%+2.7 \%$. Chlorophyll fluorescence measurements were taken with a portable fluorometer (PAM-2000, Walz, Effeltrich, Germany). Leaves were dark-adapted for at least 30 min prior to the measurements. After dark adaptation, the minimal fluorescence $\left(F_{o}\right)$ was determined using the measuring light. Subsequent application of a saturating flash of white light $\left(0.8 \mathrm{~s}\right.$ at $\left.8000 \mu \mathrm{mol} \mathrm{m} \mathrm{m}^{-2} \mathrm{~s}^{-1}\right)$ raises fluorescence to its maximum value $\left(F_{m}\right)$. This permits the determination of the $F_{v}: F_{m}$ parameter, maximum quantum efficiency of photosystem II (PSII) primary photochemistry, given by $F_{v}: F_{m}=\left(F_{m}-F_{o}\right): F_{m}$. The saturation pulse method was subsequently applied for the analysis of quenching components (Schreiber et al., 1986). After $F_{v}: F_{m}$ determination, 15 intermittent pulses of saturating strong white light $(0.8 \mathrm{~s}$ at $8000 \mu \mathrm{mol} \mathrm{m}^{-2} \mathrm{~s}^{-1}$ ) were applied in the presence of actinic red light $\left(118 \mu \mathrm{mol} \mathrm{m}^{-2} \mathrm{~s}^{-1}\right)$. This enables the determination of the maximum fluorescence in the light adapted state $\left(F_{m}{ }^{\prime}\right)$ after each saturating pulse, and the actinic light allows steady-state photosynthesis and modulated fluorescence yield at this steady state $\left(F_{s}\right)$. The minimum fluorescence in the light-adapted state $\left(F_{o}{ }^{\prime}\right)$ is also measured by applying a pulse of far-red light during a brief interruption of actinic illumination. At each saturating pulse, the quenching due to non-photochemica dissipation of absorbed light energy (NPQ) was determined according to the equation $\mathrm{NPQ}=\left(F_{m}-F_{m}{ }^{\prime}\right): F_{m}{ }^{\prime}$. The coefficient for photochemical quenching (qP), which represents the redox state of the primary electron acceptor of PSII, $Q_{A}$, was calculated as $\left(F_{m^{\prime}}-F_{s}\right):\left(F_{m}{ }^{\prime}-F_{o}{ }^{\prime}\right)$. The quantum yield of electron transfer at PSI ( $\left.\Phi_{\mathrm{PSII}}\right)$ was estimated as $\Phi_{P S I I}=F_{v}{ }^{\prime}: F_{m}{ }^{\prime}=\left(F_{m}{ }^{\prime}-F_{s}\right): F_{m}{ }^{\prime}$ (Genty et al., 1989), and the quantum efficiency of excitation capture by oxidized reaction centers of PSII was calculated from the equation $\Phi_{\text {exc }}=\left(F_{m^{\prime}}{ }^{\prime}-F_{o}{ }^{\prime}\right): F_{m^{\prime}}$. For statistical analysis, we considered the values of the last pulse, when conditions under actinic illumination were steady.

Chlorophyll content was estimated non-destructively with a portable chlorophyll meter (SPAD-520, Minolta) in the same leaves used for gas exchange and fluorescence analysis. This instrument uses measurements of transmitted radiation in the red and near-infrared wavelengths to provide numerical values related to leaf chlorophyll content. The average of three measurements was calculated for each leaf.

\section{6. $A / C_{i}$ curves}

Leaf assimilation rate responses to changes in the intercellular partial pressure of $\mathrm{CO}_{2}$ (i.e., $A / C_{i}$ response curves) were measured in 4-5 attached leaves per ozone treatment. These measurements were taken on 5 June 2005 ( 3 weeks after starting fumigation), in leaves randomly selected from those measured the day before. An infrared gas analyzer (IRGA) (LICOR-6400, Li-Cor Inc., Lincon, NE, USA) was also used for these measurements. Curves were constructed by varying the reference $\mathrm{CO}_{2}$ air concentration in the following steps: 50, 100, 200, 300, 370, 400, 600, 800 1000,1400 and $1700 \mu \mathrm{mol} \mathrm{mol}^{-1}$. Block temperature of the cuvette was fixed at $25^{\circ} \mathrm{C}$, and photon flux density (PPFD) at $1200 \mu \mathrm{mol} \mathrm{m}{ }^{-2} \mathrm{~s}^{-1}$. Maximum rate of Rubisco carboxylation $\left(V_{c, \max }\right)$, maximum RuBP regeneration capacity mediated by light harvesting and electron transport $\left(J_{\max }\right)$, rate of triose phosphate utilization (TPU) and rate of non-photorespiratory $\mathrm{CO}_{2}$ evolution in light $\left(R_{d}\right)$ were calculated from these curves using the Photosyn Assistant 1.2 software (Dundee Scientific Dundee, USA). This program uses an iterative procedure to calculate the parameter values that represent the best fit for the data, based on the model proposed by Farquhar et al. (1980), with improvements. The relative stomatal limitation of photosynthesis (RSL) was calculated according to Farquhar and Sharkey (1982) as $\mathrm{RLS}=\left(\left(A_{o}-A\right) / A_{o}\right) * 100$, where $A_{o}$ is the potential assimilation rate if there was no stomatal limitation and $A$ is the actual assimilation rate at an ambient air $\mathrm{CO}_{2}$ concentration of $C_{a}=370 \mu \mathrm{mol} \mathrm{CO}_{2} \mathrm{~mol}^{-1}$. The maximal photosynthetic rate under light and $\mathrm{CO}_{2}$ saturation $\left(A_{\max }\right)$ was calculated at $C_{a}=1400 \mu \mathrm{mol} \mathrm{CO}_{2} \mathrm{~mol}^{-1}$ in the plateau phase of $A / C_{i}$ response curves, and before a possible reduction by TPU limitation.

\subsection{Senescence and biomass partitioning}

Senescent leaves were regularly collected throughout the experiment, and the accumulated dry weight of senescent leaves per plant was calculated on a 2-week basis. At the end of the experiments (5-8 September) the 24 plants were collected and the above-ground (leaves, stems, flowers) and below-ground (roots) biomass was calculated separately after oven-drying at $60^{\circ} \mathrm{C}$ to stable weight. Roots were separated from the soil by washing them onto sieves. 


\subsection{Statistical analyses}

Differences between the two ozone treatments were determined using a $t$ test. Normality and homogeneity of variance requirements were previously tested. If these requirements were not fulfilled, a non-parametric Mann-Whitney $U$ test was applied. For senescence results, a repeated measures ANOVA test was applied. As plants were regularly moved inside chambers and among chambers in order to avoid positional effects, the unit of replication was considered to be the plant. A probability level of $\leq 0.05$ was considered statistically significant. Data were analyzed using SPSS 15.0 for Windows (SPSS Inc., Chicago, USA)

\section{Results}

\subsection{Ozone concentrations}

Ambient ozone concentrations at the experimental site were moderate during the whole exposure period (18 May-8 September 2005, a total of 113 days) (Table 1 ). In the charcoal filtered air (CF, control), hourly mean ozone concentrations were typically below $30 \mu \mathrm{g} \mathrm{m}^{-3}$, while in the $\mathrm{NF}+30$ treatment, hourly mean concentrations were about $80 \mu \mathrm{g} \mathrm{m}^{-3}$. Other descriptive means and accumulated exposures are also provided in Table 1.

\subsection{Evolution of visible symptoms}

After just 3 days of exposure to the NF+30 treatment, we observed the first symptoms on leaves of $L$. dianae: a yellow stippling that affected only the interveinal upper surface of the oldest leaves (Fig. 1A), while the youngest leaves remained unaffected. Accumulated AOT40 for the symptom onset in this species was rather low, $3512 \mu \mathrm{g} \mathrm{m}^{-3} \mathrm{~h}$. After 15 days, all 12 individuals in the NF+30 treatment were symptomatic. Symptoms were never observed in the $\mathrm{CF}$ treatment during the course of the experiment. $L$. dianae was fumigated simultaneously with several other species (including three trees, five shrubs and two herbs) and, based on visible symptoms, it was clearly the most sensitive of all (unpublished data). Visible symptoms showed a steep initial increase, followed by a stabilization period until about day 57, and then another final increase. The latter increase corresponds to a period in which more than half of the flowers had reached anthesis, seeds were mature (Fig. 2) and senescence of the older leaves was more marked in both ozone treatments (Fig. 3). In contrast to ozone-induced visible injury, senescence (as observed in CF plants) produced not an interveinal but a homogeneous yellowing that affected both the upper and lower sides of the leaves.

\subsection{Effects on leaf anatomy}

L. dianae leaves are amphystomatous, i.e., with stomata on both sides. Below the stomata there are relatively large substomatic chambers which, together with the intercellular spaces (Fig. 1B), may contribute to facilitate gas diffusion inside the leaf. Assimilatory tissue cells are very rich in chloroplasts, and their central part is occupied by a large vacuole (Fig. 1B, F). One of the initial alterations observed before the visible symptoms were well established, was an enhanced accumulation of starch in the chloroplasts (compare Fig. 1C, a CF plant, with Fig. 1D, a NF+30 plant) as well as alterations in chloroplast shape (Fig. 1G), which were usually more intense in areas or parts of the cell facing intercellular spaces or substomatal cavities. In injured leaves, starch almost disappeared (Fig. 1E) and chloroplasts were finally destroyed (Fig. 1H). Coincident with the onset of the first symptoms in the leaves, the cell walls experienced a striking alteration consisting of the accumulation of a few rounded pectinaceous wart-like exudates (Fig. 1G);
Table 1

Mean ozone concentrations for different daily time windows, AOT40 and maximum hourly value reached for the whole period covered by this experiment (from 18 May to 8 September 2005). The $8 \mathrm{~h}$ window, from 10 to $18 \mathrm{~h}$, covered the $8 \mathrm{~h}$ in which plants of the NF+30 treatment were exposed to increased ozone levels.

\begin{tabular}{llllll}
\hline & $\begin{array}{l}24 \mathrm{~h} \text { mean } \\
\text { value } \\
\left(\mu \mathrm{g} \mathrm{m}^{-3}\right)\end{array}$ & $\begin{array}{l}\text { 12 h mean } \\
{[8-20 \mathrm{CET}]} \\
\left(\mu \mathrm{g} \mathrm{m}^{-3}\right)\end{array}$ & $\begin{array}{l}8 \mathrm{~h} \text { mean } \\
{[10-18 \mathrm{CET}]} \\
\left(\mu \mathrm{g} \mathrm{m}^{-3}\right)\end{array}$ & $\begin{array}{l}\text { Maximum } \\
\text { hourly value } \\
\left(\mu \mathrm{g} \mathrm{m}^{-3}\right)\end{array}$ & $\begin{array}{l}\text { AOT40 } \\
{[8-20 \mathrm{CET}]} \\
\left(\mu \mathrm{g} \mathrm{m}^{-3} \mathrm{~h}\right)\end{array}$ \\
\hline $\mathrm{CF}$ & 21.6 & 20.6 & 24.6 & 61.6 & 0 \\
$\mathrm{NF}+30$ & 79.6 & 129.6 & 144.4 & 220.6 & 70038 \\
Ambient & 63.2 & 91.2 & 96.2 & 172 & 21732 \\
air & & & & & \\
\hline
\end{tabular}

$\mathrm{CF}$, charcoal filtered air; $\mathrm{NF}+30=$ non-filtered air $+30 \mathrm{ppb}$ ozone. Ambient air is not a treatment but refers to the ozone levels measured at the experimental site outside the open-top chambers.

these became relatively abundant in sections of symptomatic leaves (Fig. 1H). In parallel, the middle lamella of the cell walls degenerated, so that cells increased the intercellular spaces between them. Only at the end did some of these cells completely collapse (Fig. 1L, M). Ozone also produced enhanced callose accumulation on the cell walls of the palisade parenchyma and transition zone, and particularly in both the phloem and the subsidiary cells of the stomata (Fig. 1J). In contrast, in plants grown in filtered air, callose was not detected in the leaves (Fig. 1I). Phloem sieve tubes became partly obturated by the accumulation of callose and a dense substance with affinity for toluidine blue, especially on the walls and sieve plates (Fig. 1K).

\subsection{Gas exchange and chlorophyll content measurements}

Mature leaves of the ozone-enriched treatment experienced a significant $26 \%$ reduction in $A_{\text {sat }}$, a $12 \%$ increase in $C_{i}$ and a $25 \%$ decrease of WUE at saturating light conditions in relation to control leaves (Table 2). Chlorophyll content (SPAD units) also declined significantly $(10 \%)$ in these ozone-exposed leaves. On the contrary, transpiration rates and stomatal conductance to water vapor were not significantly affected (Table 2).

\section{5. $A / C_{i}$ curves}

With regard to control (CF) leaves, ozone-exposed leaves experienced a $26 \%$ decrease in the maximum carboxylation rate when ribulose biphosphate (RuBP) is saturated $\left(V_{c, \max }\right)$, and exhibited similar reductions in the maximum capacity for RuBP regeneration $\left(J_{\max }\right)$ mediated by electron transport (Table 3 ). Moreover, both parameters, $V_{c, \max }$ and $J_{\max }$, showed a strong linear correlation $\left(J_{\max }=2.35 \cdot V_{c, \max }+10.5 ; R^{2}=0.98\right)$.

At high $C_{i}$ values, $A$ may be limited by the available inorganic phosphate. The potential capacity of starch and sucrose synthesis to utilize triose phosphates and subsequently regenerate inorganic phosphate for photophosphorylation (triose phosphate utilization, TPU) declined by $20 \%$ in ozone-exposed leaves with respect to control ones. Day-time respiration $\left(R_{d}\right)$ and relative stomatal limitation (RSL) increased by $33 \%$ and $13 \%$, respectively, although not significantly, in ozonated leaves.

The maximum light- and $\mathrm{CO}_{2}$-saturated rate of assimilation $\left(A_{\max }\right)$ also declined significantly in ozone-exposed leaves.

\subsection{Chlorophyll fluorescence measurements}

Ozone induced a significant decline in the quantum yield of PSII $\left(\Phi_{P S I I}\right)$ electron transfer (Table 4$)$ and a reduction in the coefficient for photochemical quenching (qP) (nearly significant, 
$p=0.051)$. However, the maximum quantum efficiency of photosystem II (PSII) primary photochemistry $\left(F_{v}: F_{m}\right)$ was not altered by the ozone treatment; in this parameter, significant differences with regard to control leaves were observed only when measurements were carried out in clearly symptomatic leaves (data not shown).

\subsection{Senescence and biomass partitioning}

In the course of the first 43 days, there was a tendency for the ozone-fumigated plants to increase senescence (repeated measures ANOVA, $p=0.061$ ) in comparison with the control ones, although the relatively large variability between plants prevented
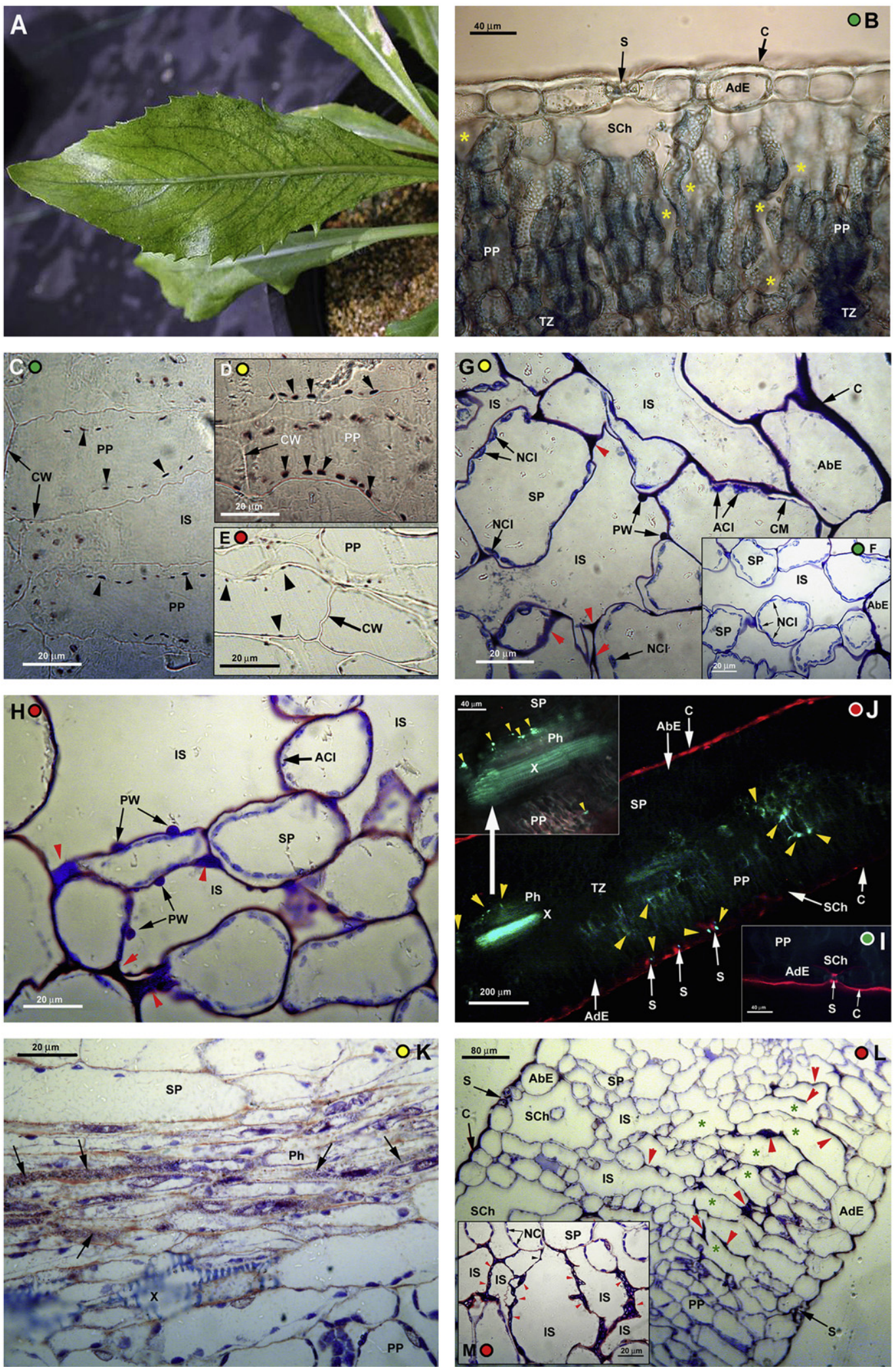


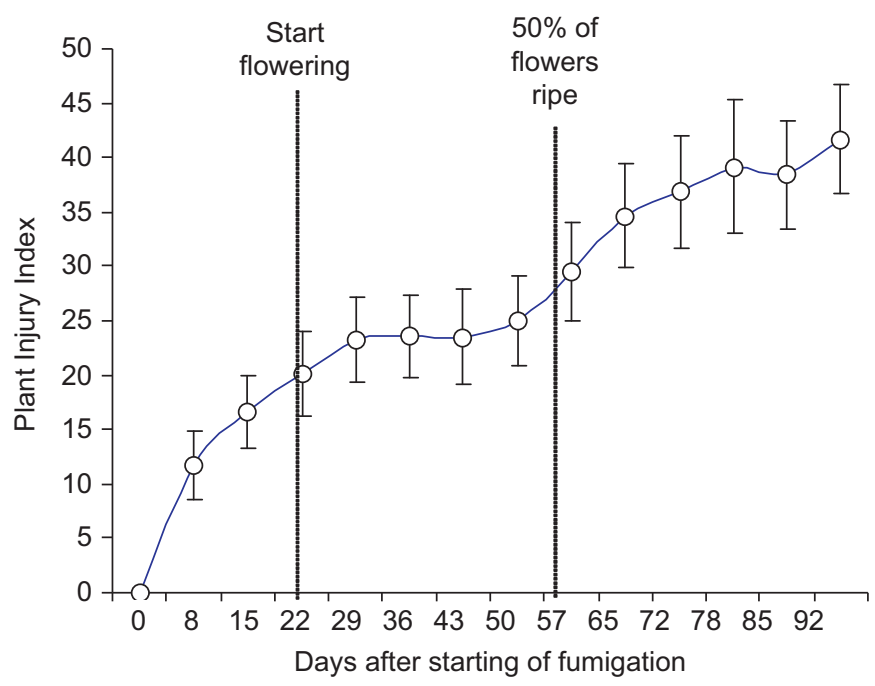

Fig. 2. Evolution of the Plant Injury Index, and dates at which the plants started to flower, produced the first ripe flowers (i.e., reached anthesis) and when $50 \%$ of the flowers were ripe. Data refer only to the ozone-enriched treatment, as charcoal filtered plants did not show visible symptoms. Mean \pm s.e., $n=12$ plants.

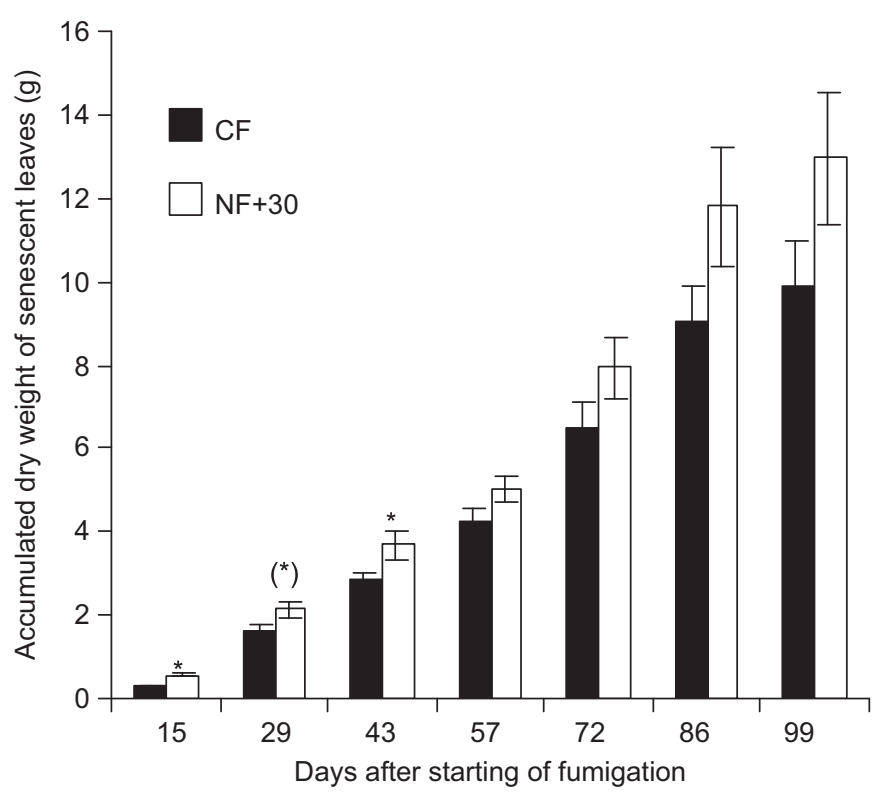

Fig. 3. Accumulated dry weight (DW) of senescent leaves per plant in the two treatments (Mean \pm s.e., $n=12$ plants, Student's $t$-test, level of significance: $\left.{ }^{*} p \leq 0.05,\left({ }^{*}\right) p=0.06\right)$. significant differences. Towards the end of the experiment, when most of the flowers had reached anthesis, leaf senescence was accelerated in both treatments, as normally occurs in this species in natural conditions towards summer (Laguna, oral com.).

Ozone fumigation did not produce any change in the total biomass of the plants, but it significantly reduced root biomass (Fig. 4A). In ozone-exposed plants, this reduction in root biomass was compensated by a tendency (not significant) to increase the above-ground biomass. While senescence processes were accelerated in older leaves of ozone-exposed plants, an enhanced production of new leaves in younger parts of the plant was observed, which may explain the here-reported tendency to increase above-ground biomass in this treatment. A clear change in the biomass partitioning took place as a result of ozone fumigation, as indicated by the below-ground/above-ground biomass quotient: in ozone-exposed plants this quotient was significantly reduced (Fig. 4B).

\section{Discussion}

In the present paper, the responses of the endemic plant L. dianae to ozone are characterized at different but interlinked levels: from physiology and anatomy to biomass partitioning. Results of the present study show that this species has a high sensitivity to ozone, at least in terms of onset and severity of visible injury. In comparison, Viburnum lantana and Hybiscus syriacus, two species that were fumigated in parallel with L. dianae in the year 2005 and that are considered as being very sensitive to ozone (Paoletti et al., 2009; Calatayud et al., 2010), developed symptoms later and less extensively. Amphystomatous leaf type, relatively large substomatic chambers and abundant intercellular spaces are anatomical features that reduce leaf resistance to gas exchange and therefore favor ozone diffusion inside the leaves (Lyons et al., 2000; Calatayud et al., 2011). Species with relatively high stomatal conductance, as is the case of Lamottea, might be more susceptible to the detrimental effects of oxidants, including more visible injury and impaired $\mathrm{CO}_{2}$ assimilation (Reich, 1987). However, it is well-known that, in addition to ozone uptake, the detoxification and repair capacity of the plant also accounts for plant sensitivity to this pollutant (Kangasjärvi et al., 1994; Nali et al., 2004; Calatayud et al., 2010, 2011).

In ozone-exposed but asymptomatic leaves (representative of early effects), some anatomical alterations begin to take place. Although still restricted to certain mesophyll areas, thickenings and wart-like protrusions in the cell walls, as well as slight changes in chloroplast shape, can be observed. These alterations will become more evident in symptomatic leaves. These wall alterations are indicative of oxidative processes associated with

Fig. 1. Visible symptoms and anatomical alterations produced by ozone. Codes of the circles: green $=$ control leaf; yellow $=\mathrm{NF}+30$ leaf, asymptomatic; red $=\mathrm{NF}+30$ leaf, with visible injury. (A) Intervenial yellow stippling in Lamottea leaves. (B) Cryosection of a healthy leaf from the CF treatment; note the large substomatic chamber (SCh) and the abundance of intercellular spaces $\left(^{*}\right)$ between palisade parenchyma cells (PP). (C) Filtered leaves. Starch accumulation (black arrow heads) in chloroplasts of the palisade parenchyma (PP) in semithin sections stained with Lugol. (D) Enhanced starch accumulation (black arrow heads) in asymptomatic but ozone-exposed leaves. (E) Cells of a symptomatic leaf with a few altered chloroplasts and reduced starch accumulation (black arrow heads). (F) Semithin section stained with toluidine blue (TB) of a control plant leaf (CF) showing the chloroplasts rather homogeneously distributed in the peripheral parts of the cytoplasm of spongy parenchyma (SP) cells. (G) Semithin section stained with TB of an ozone-exposed asymptomatic leaf, with small pectinaceous wart-like exudates (PW), and both normal (NCl) and altered chloroplasts (ACl). Note the presence of areas of collapsed cells with thickened walls (red arrow heads). (H) Semithin section stained with TB of an injured leaf, with abundant and large pectinaceous wart-like exudates (PW), and some degenerated chloroplasts ( $\mathrm{ACl}$ ). Note the presence of areas of degraded cell walls (red arrow heads). (I) Cryosection of a control leaf observed under fluorescence after aniline staining to detect callose; note the absence of fluorescence except the normal fluorescence of the cuticle (C). (J) The same as (I) but in an injured leaf; note the accumulation of callose (bluish fluorescence; yellow arrow heads) in cell walls of the palisade parenchyma (PP), in the subsidiary cells of the stomata (S) and in the phloem (detail); fluorescence in the xylem occurred also in control leaves. (K) Semithin section stained with TB. Accumulation of callose and of a dense substance with affinity for toluidine blue, especially on the walls and sieve plates of the phloem sieve tubes (arrows). (L) and (M) Semithin sections stained with TB of injured leaves with areas of collapsed cells with thickened walls (red arrow heads). Abbreviations: ACl, altered chloroplasts; C, cuticle; AbE, abaxial epidermis; AdE, adaxial Eepidermis; IS, intercellular space; $\mathrm{NCl}$, normal chloroplasts; Ph, phloem; PW: pectinaceous wart-like exudates; PP, palisade parenchyma; S, stoma; SP, spongy parenchyma; CW, cellular wall; CM, cellular membrane; X, xylem; TZ, transition zone. (For interpretation of the references to color in this figure legend, the reader is referred to the web version of this article.) 
Table 2

Gas exchange parameters after 3 weeks of fumigation (mean \pm s.e.).

\begin{tabular}{|c|c|c|c|c|c|c|}
\hline & $\begin{array}{l}A_{\text {sat }} \\
\left(\mu \mathrm{mol} \mathrm{CO} \mathrm{m}^{-2} \mathrm{~s}^{-1}\right)\end{array}$ & $\begin{array}{l}g_{s} \\
\left(\mu \mathrm{mol} \mathrm{CO} \mathrm{m}^{-2} \mathrm{~s}^{-1}\right)\end{array}$ & $\begin{array}{l}C_{i} \\
\left(\mu \mathrm{mol} \mathrm{CO} \mathrm{mol}^{-1}\right)\end{array}$ & $\begin{array}{l}T_{r} \\
\left(\mathrm{mmol} \mathrm{H}_{2} \mathrm{O} \mathrm{m}^{-2} \mathrm{~s}^{-1}\right)\end{array}$ & $\begin{array}{l}\text { WUE } \\
\left(\mu \mathrm{mol} \mathrm{CO} \mathrm{mmol}^{-1} \mathrm{H}_{2} \mathrm{O}\right)\end{array}$ & $\begin{array}{l}\text { SPAD } \\
\text { (a.u.) }\end{array}$ \\
\hline $\mathrm{CF}$ & $19.1 \pm 1.0 a$ & $275 \pm 23 a$ & $224.9 \pm 4.8 \mathrm{a}$ & $3.2 \pm 0.2 \mathrm{a}$ & $5.9 \pm 0.2 \mathrm{a}$ & $58.8 \pm 1.1 \mathrm{a}$ \\
\hline $\mathrm{NF}+30$ & $14.1 \pm 1.0 \mathrm{~b}$ & $246 \pm 20 a$ & $252.0 \pm 7.4 b$ & $3.2 \pm 0.2 \mathrm{a}$ & $4.4 \pm 0.3 b$ & $53.2 \pm 1.9 b$ \\
\hline
\end{tabular}

Significant differences between treatments are indicated with different letters ( $n=8$; Student's $t$-test, $p \leq 0.05$ ).

Table 3

Photosynthetic parameters derived from $A / C_{i}$ curves after 3 weeks of fumigation (mean \pm s.e.).

\begin{tabular}{|c|c|c|c|c|c|c|}
\hline & $\begin{array}{l}A_{\max } \\
\left(\mu \mathrm{mol} \mathrm{CO} \mathrm{CO}_{2} \mathrm{~m}^{-2} \mathrm{~s}^{-1}\right)\end{array}$ & $\begin{array}{l}V_{c, \max } \\
\left(\mu \mathrm{mol} \mathrm{CO} \mathrm{CO}_{2} \mathrm{~m}^{-2} \mathrm{~s}^{-1}\right)\end{array}$ & $\begin{array}{l}J_{\max } \\
\left(\mu \mathrm{mol} \text { elect. } \mathrm{m}^{-2} \mathrm{~s}^{-1}\right)\end{array}$ & $\begin{array}{l}\text { TPU } \\
\left(\mu \mathrm{mol} \mathrm{CO} \mathrm{m}^{-2} \mathrm{~s}^{-1}\right)\end{array}$ & $\begin{array}{l}R_{d} \\
\left(\mu \mathrm{mol} \mathrm{CO} 2 \mathrm{~m}^{-2} \mathrm{~s}^{-1}\right)\end{array}$ & $\begin{array}{l}\mathrm{RSL} \\
(\%)\end{array}$ \\
\hline $\mathrm{CF}$ & $37.1 \pm 0.4 a$ & $92.6 \pm 5.4 a$ & $229.1 \pm 14.0 \mathrm{a}$ & $12.6 \pm 0.4 a$ & $1.2 \pm 0.2 \mathrm{a}$ & $35.0 \pm 2.6 a$ \\
\hline$N F+30$ & $26.8 \pm 0.6 b$ & $68.8 \pm 5.6 b$ & $170.1 \pm 14.3 b$ & $10.1 \pm 0.6 b$ & $1.6 \pm 0.3 a$ & $39.4 \pm 5.5 a$ \\
\hline
\end{tabular}

Significant differences between treatments are indicated with different letters $(n=4-5, U$ Mann-Withney test, $p \leq 0.05)$.

Table 4

Chlorophyll fluorescence parameters after 3 weeks of fumigation (mean \pm s.e.).

\begin{tabular}{|c|c|c|c|c|c|c|c|}
\hline & $F_{v}: F_{m}$ & $F_{m}$ & $F_{o}$ & $\Phi_{P S I I}$ & $\mathrm{qP}$ & NPQ & $\Phi_{e x c}$ \\
\hline $\mathrm{CF}$ & $0.826 \pm 0.005 a$ & $1.457 \pm 0.033 a$ & $0.253 \pm 0.005 a$ & $0.645 \pm 0.005 a$ & $0.878 \pm 0.012 \mathrm{a}$ & $0.361 \pm 0.033 a$ & $0.735 \pm 0.005 a$ \\
\hline $\mathrm{NF}+30$ & $0.815 \pm 0.006 a$ & $1.494 \pm 0.062 a$ & $0.276 \pm 0.013 a$ & $0.619 \pm 0.009 b$ & $0.841 \pm 0.012 \mathrm{a}$ & $0.437 \pm 0.043 a$ & $0.737 \pm 0.007 a$ \\
\hline
\end{tabular}

Significant differences between treatments are indicated with different letters ( $n=8$; Student's $t$-test, $p \leq 0.05$ ).

A

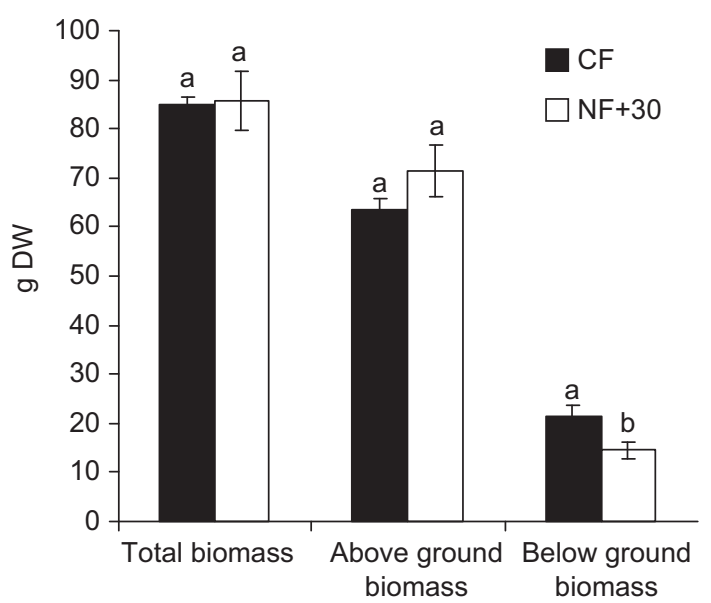

$\mathrm{B}$

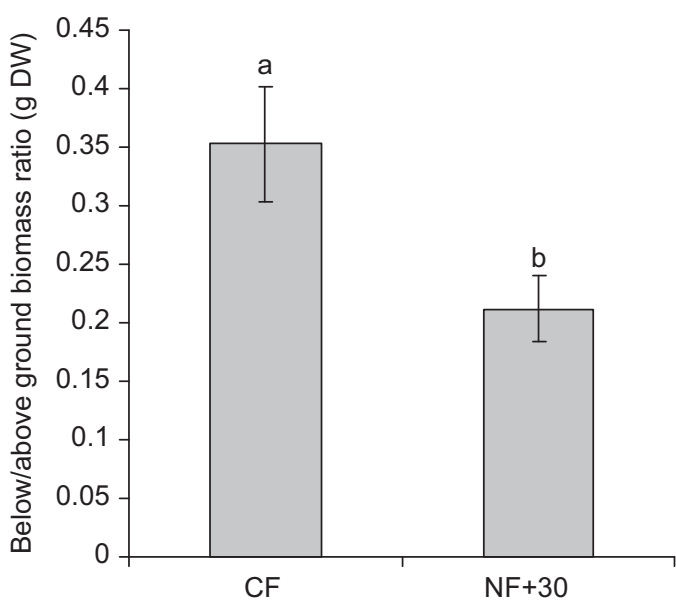


$n=12$ plants, Student's $t$-test, level of significance: $p \leq 0.05$, significant differences between both treatments are indicated with different letters.

the apoplastic oxidative burst caused by ozone (Günthardt-Goerg et al., 1997; Reig-Armiñana et al., 2004). On the other hand, the observed impairment of $\mathrm{CO}_{2}$ assimilation and the progressive alterations of chloroplasts confirm that photosynthetic processes are affected by this pollutant. In fumigated leaves, the significant reductions (with respect to control leaves) in $A_{\text {sat }}$ and $A_{\max }$ were not well explained either by photoinhibitory damage $\left(F_{v}: F_{m}\right.$ not affected) (Maxwell \& Johnson, 2000) or by stomatal limitations. Stomatal conductance and RSL were not significantly affected by ozone, $C_{i}$ increased and WUE declined, whereas reductions in $C_{i}$ and increases in WUE would be expected in stomata-limited gas exchange conditions (Reichenauer and Bolhàr-Nordenkampf, 1999; Calatayud et al., 2007). The clear decline in $V_{c, \max }$ suggests that, in agreement with previous studies (e.g., Farage and Long, 1999), a reduction of the in vivo Rubisco carboxylation efficiency is one of the primary changes responsible for a decline in $\mathrm{CO}_{2}$ assimilation in ozone-fumigated plants. Ozone produces a reduction in the amount of active carboxylation activity (acceptance of $\mathrm{CO}_{2}$ ) of the Rubisco enzyme (Enyedi et al., 1992), either by direct oxidation of Rubisco protein (Pell et al., 1994) or by decreasing the transcript levels of Rubisco-encoding mRNAs (Reddy et al., 1993; Goumenaki et al. 2010). Relevant changes in the light 
harvesting component seem to be secondary (Reichenauer and Bolhàr-Nordenkampf, 1999; Calatayud et al., 2007). The observed physiological responses are very similar to those taking place during senescence. A decline in the stromatic protein Rubisco is considered a key senescence event leading to reduced photosynthetic activity (Crafts-Brandner et al., 1990), while degradation of thylakoid proteins and important effects in the light harvesting system such as a decline in $F_{v}: F_{m}$ are usually delayed to later senescence phases (Humbeck et al., 1996). In fumigated leaves of the present experiment, there was a tendency to reduce the light energy used in photochemistry (indicated by a significant decrease in $\Phi_{P S I I}$ and a reduction in $\mathrm{qP}$ ) at the expense of heat dissipation (NPQ increases). In senesced leaves, the same kinds of changes have been observed, and they are thought to contribute to down-regulate photosynthesis by adapting ATP and NADPH production to the lowered demand of the Calvin Cycle ( $\mathrm{Lu}$ and Zhang, 1998). The changes in $\Phi_{P S I I}$ in ozone-fumigated leaves could be interpreted in the same way (Calatayud et al., 2003; Calatayud et al., 2007). These results would then be consistent with the idea that ozone effects on Rubisco (and on some chlorophyll fluorescence parameters) could be, at least partly, related to the accelerated senescence triggered by this pollutant (Overmyer et al., 2005; Goumenaki et al., 2010). It is also interesting to note that in ozone-exposed leaves, $J_{\max }$ also declined. The observed strong correlation between $V_{c, \max }$ and $J_{\max }$ indicates that there is a close functional balance between Rubisco carboxylation efficiency and maximum RuBP regeneration capacity (Wullschleger, 1993; Goumenaki et al., 2010). The regeneration of RuBP is a highly regulated process involving not only the light-harvesting complexes and the whole electron-transport chain, but also chloroplast membranes and Calvin Cycle enzymes apart from Rubisco (Farquhar and Sharkey, 1982). The 33\% increase in daytime respiration $\left(R_{d}\right)$, although not significant, may reflect some enhancement in the metabolic activity devoted to detoxification and repair processes.

From an anatomical point of view, ozone induced different types of responses. In addition to the increase in pectinaceous wart-like exudates in the cell walls, indicative of oxidative stress, there was also a clear increase in callose deposition. Callose accumulation is a defense response to abiotic and biotic factors such as wounding, desiccation, metal toxicity or insect attacks, and it has been postulated that it might act as a physical barrier against microbial and fungal attack (Stone and Clarke, 1992), isolating affected tissues from healthy cells. Ozone is considered to be an abiotic elicitor inducing responses similar to plant defense responses to pathogen attacks (Sandermann et al., 1998); callose accumulation in ozone-exposed leaves has previously been reported in several studies (Gravano et al., 2003; Bussotti et al., 2005; García-Breijo et al., 2008).

Results of the present study also show that ozone altered biomass partitioning mainly by reducing below-ground biomass (the roots). A reduction in root biomass or in the below-ground/ above-ground ratio has been reported as an ozone effect in different species (e.g., Andersen, 2003; US Environmental Protection Agency, 1996), reflecting a decrease in photoassimilate allocation from source tissues (leaves) to sink tissues (roots). Ozone may affect transport processes resulting in an inhibition of sucrose export and an accumulation of carbohydrates and starch (Rennenberg et al., 1996). Several microscopy studies have shown an accumulation of starch along leaf veins of Populus or Betula (Matyssek et al., 1992; Landolt et al., 1997) or, similarly to the present study, filling chloroplasts in Pinus halepensis (Wellburn and Wellburn, 1994) after ozone exposure. This accumulation has been related to decreased or inhibited phloem loading, which would produce enhanced sucrose levels in leaves, so that starch accumulation would be favored in order to decrease $\mathrm{C}$ flow towards sucrose synthesis (Landolt et al., 1997). In injured leaves of $L$. dianae, both callose and a denser substance accumulate in the sieve tubes and probably limit phloem activity. The consequences of root reduction in a hemicryptophytic plant like L. dianae may be relevant for the survival of this species. Most aerial parts of Lamottea desiccate towards the end of summer, after flower and seed production. A basal rosette and, later, only the buds may remain above ground, so that in this period the plant depends on root reserves for survival. These reserves are mobilized for new growth in autumn, towards October (J. Perez, pers. com.). By reducing roots, ozone may affect this forb in two different ways. First, root reserves are necessary for growth initiation, in a period in which photosynthesis is not sufficient to sustain plant respiration. Second, a less-developed root system may represent a constraint both for plant resistance to stress conditions and for reproductive success, as soil becomes increasingly dry towards summertime. However, extrapolation of these results to field conditions is difficult, as in this experiment we did not simulate a dry period towards the end of summer. Considering the biology and habitat requirements of this species, it is probable that the high-ozone episodes most likely to produce adverse effects in $L$. dianae are those that take place in spring, when gas exchange in the plants is not limited by the dry conditions and high temperatures prevailing in summer.

\section{Conclusions}

In summary, increasing ozone levels in eastern Spain might represent a threat for the endemic plant $L$. dianae. In the Mediterranean area, relatively high ozone levels can occur in spring (Sanz et al., 2007) when plants are not water-stressed. If these high-ozone episodes affect the $\mathrm{CO}_{2}$ assimilation capacity of $L$. dianae leaves, thus reducing both WUE and possibly root system development as well, as shown in this experiment, they might also contribute to reducing the capacity of these plants to withstand the subsequent drier summer conditions. Endemic plants are highly valuable species; in fact, they are currently a top priority for protection and surveillance. In a world with increasing ozone levels, knowledge on the sensitivity of endemic plants to this pollutant, including the characterization of its effects, represents important information aimed at predicting present and future risks for these highly valuable components of the ecosystem. To date, this information is practically nonexistent.

\section{Acknowledgments}

We thank the Conselleria de Medi Ambient, Aigua, territory i Habitatge and FEDER funds (project VegetPollOzone, Interreg IIIb, Meddoc) for supporting parts of this study. The Instituto Universitario CEAM-UMH is partly supported by Generalitat Valenciana, Fundación Bancaja, and benefits form the projects CONSOLIDER-INGENIO 2010 (GRACCIE) and Prometeo Program (Generalitat Valenciana). Emilio Laguna and Mari Carmen Escrivá are also thanked for providing us the plants and, together with Joan Pérez, for their comments on aspects of the biology of this species. Carmen Martín is thanked for taking care of the plants. Four anonymous referees provided very useful comments for improving the manuscript.

\section{References}

Andersen, C.P., 2003. Source-sink balance and carbon allocation below ground in plants exposed to ozone. New Phytol. 157, 213-228. 
Bussotti, F., Agati, G., Desotgiu, R., Matteini, P., Tani, C., 2005. Ozone foliar symptoms in woody plant species assessed with ultrastructural and fluorescence analysis. New Phytol. 166, 941-955.

Calatayud, A., Iglesias, D.J., Talón, M., Barreno, E., 2003. Effects of 2-month ozone exposure in spinach leaves on photosynthesis, antioxidant systems and lipid peroxidation. Plant Physiol. Biochem. 41, 839-845.

Calatayud, V., Cerveró, J., Sanz, M.J., 2007. Foliar, physiological and growth responses of four maple species exposed to ozone. Water Air Soil Pollut. $185,239-254$

Calatayud, V., Marco, F., Cerveró, J., Sánchez-Peña, G., Sanz, M.J., 2010. Contrasting ozone sensitivity in related evergreen and deciduous shrubs. Environ. Pollut. 158, 3580-3587.

Calatayud, V., Cerveró, J., Calvo, E., García-Breijo, F.J., Reig-Armiñana, J., Sanz, M.J., 2011. Responses of evergreen and deciduous Quercus species to enhanced ozone levels, Environ. Pollut. 159, 55-63.

Crafts-Brandner, S.J., Salvucci, M.E., Egli, D.B., 1990. Changes in ribulose bisphosphate carboxylase/oxygenase and ribulose 5-phosphate kinase abundance and photosynthetic capacity during leaf senescence. Photosynth. Res. 23, 223-230.

Enyedi, A.J., Eckardt, N.A., Pell, E.J., 1992. Activity of ribulose bisphosphate carboxylase/oxygenase from potato cultivars with differential response to ozone stress. New Phytol. 122, 493-500.

EU European Union Directive, 2002. 2002/3/EC of the European Parliament and of the Council of 12 February 2002 relating to ozone in ambient air. Official Journal of the European Communities L 67, 14-30.

Farage, P.K., Long, S.P., 1999. The effects of $\mathrm{O}_{3}$ fumigation during leaf development on photosynthesis of wheat and pea: an in vivo analysis. Photosynth. Res. 59, $1-7$.

Farquhar, G.D., Sharkey, T.D., 1982. Stomatal conductance and photosynthesis. Ann. Rev. Plant Physiol. 33, 317-345.

Farquhar, G.D., Von Caemmerer, S., Berry, J.A., 1980. A biochemical model of photosynthetic $\mathrm{CO}_{2}$ assimilation in leaves of $\mathrm{C} 3$ species. Planta 149, 78-90.

García-Breijo, F.J., Calatayud, V., Cerveró, J., Reig-Armiñana, J., Sanz, M.J., 2005 Anatomical and reproductive effects of ozone in the endemic Mediterranean plant Lamottea dianae. Lucknow, India: ICPEP-3 Abstract Book, 104-105.

García-Breijo, F.J., Reig-Armiñana, J., Bautista-Peris, B., Calatayud, V., Cerveró, J., Sanz, M.J., 2008. Effets anatomiques de l'ozone sur le térébinthe (Pistacia terebinthus). Forêt Méditerranéenne 29, 13-22.

Genty, B., Briantais, J.M., Baker, N.R., 1989. The relationship between the quantum yield of photosynthetic electron transport and quenching of Chl fluorescence. Biochim. Biophys. Acta 990, 87-92.

Goumenaki, E., Taybi, T., Borland, A., Barnes, J., 2010. Mechanisms underlying the impacts of ozone on photosynthetic performance. Environ. Exp. Bot. 69, 259-266.

Gravano, E., Giulietti, V., Desotgiu, R., Bussotti, F., Grossoni, P., Gerosa, G., Tani., C., 2003. Foliar response of an Ailanthus altissima clone in two sites with different levels of ozone-pollution. Environ. Pollut. 121, 137-146.

Günthardt-Goerg, M.S., McQuattie, C.J., Scheidegger, C., Rhiner, C., Matyssek, R. 1997. Ozone-induced cytochemical and ultra-structural changes in leaf mesophyll cell walls. Can. J. For. Res. 27, 453-463.

Heagle, A.S., Body, D.E., Heck, W.W., 1973. An open-top field chamber to assess the impact of air pollution on plants. J. Environ. Qual. 2, 365-368.

Humbeck, K., Quast, S., Krupinska, K., 1996. Functional and molecular changes in the photosynthetic apparatus during senescence of flag leaves from fieldgrown barley plants. Plant Cell Environ. 19, 337-344.

Kangasjärvi, J., Talvinen, J., Utriainen, M., Karjalainen, R., 1994. Plant defense systems induced by ozone: commissioned review. Plant Cell Environ. 17, 783-794.

Krupa, S., McGrath, M.T., Andersen, C.P., Booker, F., Burkey, K.O., Chappelka, A.H., Chevone, B.I., Pell, E.J., Zilinskas, B.A., 2000. Ambient ozone and plant health. Plant Dis. 85, 4-12.

Laguna, E., Ballester, G., Escribá, M.C., Arregui, J.M., Juárez, J., Navarron, L., 1998. Introducciones y reforzamientos poblacionales de especies amenazadas en la Comunidad Valenciana. Conservación Vegetal 3, 4-5.

Landolt, W., Gunthardt-Goerg, M.S., Pfenninger, I., Einig, W., Hampp, R., Maurer, S., Matyssek, R., 1997. Effect of fertilization on ozone-induced changes in the metabolism of birch (Betula pendula) leaves. New Phytol. 137, 389-397.

Lelieveld, J., Berresheim, H., Borrmann, S., Crutzen, P.J., Dentener, F.J., Fischer, H., Feichter, J., Flatau, P.J., Heland, J., Holzinger, R., Korrmann, R., Lawrence, M.G., Levin, Z., Markowicz, K.M., Mihalopoulos, N., Minikin, A., Ramanathan, V., de Reus, M., Roelofs, G.J., Scheeren, H.A., Sciare, J., Schlager, H., Schultz, M.,
Siegmund, J., Steil, B., Stephanou, E.G., Stier, P., Traub, M., Warneke, C., Williams, J., Ziereis, H., 2002. Global air pollution crossroads over the Mediterranean. Science 298, 794-799.

Lu, C.-M., Zhang, J., 1998. Modifications in photosystem II photochemistry in senescent leaves of maize plants. J. Exp. Bot. 49, 1671-1679.

Lyons, T., Plöch, M., Turcsány, E., Barnes, J., 2000. Extracellular antioxidants: a protective screen against ozone?. In: Environmental Pollution and Plant Responses. Lewis Publishers, Boca Raton, London, New York, Washington, 183-201

Matyssek, R., Günthardt-Goerg, M.S., Saurer, M., Keller, T., 1992. Seasonal growth, $\delta^{13} \mathrm{C}$ in leaves and stem, and phloem structure of birch (Betula pendula) under low ozone concentrations. Trees Struct. Funct. 6, 69-76.

Maxwell, K., Johnson, G.N., 2000. Chlorophyll fluorescence-a practical guide. J. Exp. Bot. 51, 659-668.

Millán, M.M., Salvador, R., Mantilla, E., Artíñano, B., 1996. Meteorological and photochemical air pollution in Southern Europe: experimental results from EC research projects. Atmos. Environ. 30, 1909-1924.

Millán, M., Mantilla, E., Salvador, R., Carratalá, A., Sanz, M.J., Alonso, L., Gangoiti, G. Navazo, M., 2000. Ozone cycles in the Western Mediterranean Basin: interpretation of monitoring data in complex coast terrain. J. Appl. Meteorol. 39, 487-508.

Nali, C., Paoletti, E., Marabottini, R., Della Rocca, G., Lorenzini, G., Paolacci, A.R. Ciaffi, M., Badiani, M., 2004. Ecophysiological and biochemical strategies of response to ozone in Mediterranean evergreen broadleaf species. Atmos. Environ. 38, 2247-2257.

Overmyer, K., Brosché, M., Pelinen, R., Kuittinen, T., Tuominen, H., Ahlfors, R., Keinänen, M., Saarma, M., Scheel, D., Kangasjärvi, J., 2005. Ozone-induced programmed cell death in the Arabidopsis radical-induced cell death 1 mutant. Plant Physiol. 137, 1092-1104.

Paoletti, E., Ferrara, A.M., Calatayud, V., Cerveró, J., Sanz, M.J., 2009. Deciduous shrubs for ozone bioindication: Hibiscus syriacus as an example. Environ. Pollut. 157, 865-870.

Pell, E.J., Eckardt, N., Glick, R.E., 1994. Biochemical and molecular basis for the impairment of photosynthetic potential. Photosynth. Res. 39, 453-462.

Reddy, G.N., Aeteca, R.N., Dai, Y.R., Flores, H.E., Negram, F.B., Pell, E.J., 1993. Changes in ethylene and polyamines in relation to mRNA levels of the large and small subunits of ribululose bisphosphate/oxygenase in ozone-stressed potato foliage. Plant Cell Environ. 120, 819-826.

Reich, P.B., 1987. Quantifying plant response to ozone: a unifying theory. Tree Physiol. 3, 63-91.

Reichenauer, T.G., Bolhàr-Nordenkampf, H.R., 1999. Mechanisms of impairment of the photosynthetic apparatus in intact leaves by ozone. Z. Naturforsch. 54c, 824-829.

Reig-Armiñana, J., Calatayud, V., Cerveró, J., García-Breijo, F.J., Ibars, A., Sanz, M.J., 2004. Effects of ozone on the foliar histology of the mastic plant (Pistacia lentiscus L.). Environ. Pollut. 132, 321-331.

Rennenberg, H., Herschbach, C., Polle, A., 1996. Consequences of air pollution on shoot-root interactions. J. Plant Physiol. 148, 296-301.

Sandermann, H., Ernst, D., Heller, W., Langebartels, C., 1998. Ozone: an abiotic elicitor of plant defence reactions [review]. Trends Plant Sci. 3, 47-50.

Sanz, M.J., Calatayud, V., Sanchez, G., 2007. Measures of ozone concentrations using passive sampling in forests of South Western Europe. Environ. Pollut. 145, 620-628.

Schreiber, U., Schliwa, U., Bilger, W., 1986. Continuous recording of photochemical and non-photochemical chlorophyll fluorescence quenching with a new type of modulation fluorometer. Photosynth. Res. 10, 51-62.

Stone, B.A., Clarke, A.E., 1992. Chemistry and Biology of $(1 \rightarrow 3) \beta$-D-Glucans. La Trobe University Press, Melbourne.

US Environmental Protection Agency, 1996. Air Quality Criteria for Ozone and Related Photochemical Oxidants, II. Office of Research and Development, Washington DC, USA.

Vingarzan, R., 2004. A review of surface $\mathrm{O}_{3}$ background levels and trends. Atmos. Environ. 38, 3431-3442.

Domínguez-Lozano, F., 2000. Lista Roja de Flora Vascular Española (valoración según categorías UICN), Conservación Vegetal 6 (extra), pp. 11-38.

Wellburn, F.A.M., Wellburn, A.R., 1994. Atmospheric ozone affects carbohydrate allocation and winter hardiness of Pinus halepensis (Mill.). J. Exp. Bot. 274, 607-614.

Wullschleger, S.D., 1993. Biochemical limitations to carbon assimilation in C3 plants-a retrospective analysis of the $A / C_{i}$ curves from 109 species. J. Exp. Bot 44, 907-920. 